\title{
America's Coöperation Needed for the Rehabilitation of Europe
}

\author{
By George N. Barnes
}

House of Commons, London, England, Minister Plenipotentiary, Paris Peace Conference, 1919

\begin{abstract}
AL well wishers to their kind canA not but deplore the present unsettled world conditions and the tragic results arising therefrom.
\end{abstract}

The Great War would almost seem to have been waged in vain, for the high hopes which sustained the allied and associated peoples during its horrors have not been realized. We fought the War to get rid of Militarism and Europe still groans under armsEurope has now as many men in uniform as in 1913. We lived in the vain belief that release from the German menace would enable us to apply our means and resources to the plentiful production of those things which would bless and fertilize the homes of the people. And now we find ourselves engulfed in poverty deeper and bleaker than any in our pre-war modern experience.

What are the causes of this post-war anti-climax? As regards initial causes, there will, of course, be common agreement. The waste of war and the dislocation of trade and commerce were the first causes of our abnormal troubles. But it is now three years and a half since the War ended and we have made but little progress toward betterment. Yet the mere statement of the present troubles and of their initial causes would surely seem to indicate the road upon which we must travel to find and apply the remedies.

The troubles are world-wide. They began with the War. The world has been thrown out of joint. There are countries which have neither credit nor productive power to create it, and there are others whose productive capacity is unimpaired but which have lost the markets wherein to sell. Hence unemployment and poverty with attendant evils! And these can be effectively dealt with only by the emergence and application of the same spirit of coöperation in which we waged the War. No small sectional or even national measures will suffice. These will be, as they have already been, submerged by the great ocean sweep of world-wide causes. We must deal with our post-war problems as worldproblems and in the light of interrelated economic facts.

But, alas! instead of being imbued with a coöperative spirit, nations and classes appear to be guided and animated even more than in pre-war days by the spirit of conflict. Therein lie the causes of our present troubles. There is an ultra and irrational nationalism on the one hand and an equally ultra and irrational inter-nationalism on the other. The first was born of the undue emphasis laid on the principle of self-determination and it has produced a frenzy of spurious national feeling which scorches and blights all around it - especially in the new and the small states. The second is the product of that class-war teaching which has found tragic expression in Russia and which has also produced industrial conflict, with its loss and waste, in all lands-eighty-eight million working days' product was lost in England last year by strike and lock-out.

The first need of a disrupted and impoverished world, then, is a change of heart. But, as a means to that end, we need better international organization in the light of facts regarding the 
past knowledge of the true basis of hope for the future.

\section{Liquidation of War Problems}

What are the facts? First, we should be clear about the War-how it came and what it involved. The democratic countries in Europe did not want war. It was forced upon them. They had either to accept war or accept dominance of an autocratic power. But, once war began, the allied peoples became committed, not only to the liberation of peoples subject to alien rule, but also to the further task of guiding and guarding the new states during their essays in self-government. No man seemed to recognize that more clearly than President Wilson, whose noble advocacy of the rights of peoples found an echo in all lands and became enshrined in the League of Nations Covenant. But, if this be conceded, it then follows that all those who engaged in the War were committed to render their help in the liquidation of the problems arising out of it. The subject peoples became the wards of all who fought for their liberation. The liquidation of all the aftermath of war became, in fact, as important an obligation as the settlement of the terms of peace. Until that liquidation is complete, the War, in a very real sense, is still unfinished. It will not be finished until the nations are living in security or until minorities of race and of religion are assured of protection and opportunity for self-expression. Those were the ideals which animated the democratic peoples during the War, and they should have been regarded by the allied and associated governments as the legitimate fruits of victory to be gathered in before separating.

But now, in the light of these considerations, let me put some facts in regard to the attitude of the United
States in the War and after it. Let me put them bluntly and without circumlocution. After all, there should be perfect candor between friends. For the first three dreadful years of struggle, Europe sacrificed the best and bravest of its young manhood while the United States piled up profits in the manufacture of firearms. Only after three years did the United States begin to realize that Great Britain and her allies were fighting for American as well as for European freedom. From then on the United States poured out men and money in the winning of the victory in the field of battle but grew weary of well-doing when the destructive work of the soldier had to be laid aside for the constructive work of the statesman. The apparent unconcern of the United States in regard to this latter office has led to added trouble for Europe.

\section{Consequences of American Separation}

Take, for instance, the problems of the Near East. Delay in their settlement has enabled the Turk to rear his head again to resume authority over lands which he had blighted by his misrule and to regain power over the remnants of peoples whom he had almost exterminated by his lust and ferocity. And there has been no word of concern from America, no offer of help to save. Yet Europe was led to believe by President Wilson that his fellow-countrymen were concerned about the Armenians and the Christian minorities who were under Turkish domain. Paris peace delegates were under the impression that the settlement with the Turk could be safely left till problems nearer home had been disposed of. But, when the Turkish settlement had to be made, the United States was practically out of the picture and the subsequent situation, 
aggravated by Greek chauvinism, was skillfully exploited by Turkish diplomacy.

Again, the failure of the United States to ratify the pact to protect France against possible future aggression has been a cause of bloated armaments in that country, which in turn have afforded a plea or pretext for bloated armaments in other countries. And, finally, the infant League of Nations, which was launched into existence under the guidance and inspiration of President Wilson, has been left "in the air" by his fellowcountrymen.

I submit then that on a consideration of the facts of the past, and especially of the events following upon American separation from the Allies, Europe could fairly claim reconsideration of her attitude on the part of the United States of America. Participation in the War and in the terms of peace constitute, in the light of subsequent facts, a claim for resumed participation by America in the reconstruction and rehabilitation of a disrupted world.

We are all grateful for the initiative of the United States Government which led to the great conference at Washington ${ }^{\mathrm{t}}$ but what is needed is not only ad hoc conferences for special purposes but continued and sustained coöperation so that there may be a common policy maintained and enforced by the weight of all concerned.

Land and air armaments remain to be dealt with. And they fail to be dealt with in the light of another significant fact which has emerged from the War. Russia today largely determines the armaments of Europe. She has nearly a million and a half of men under arms. Poland is on the Russian border and can scarcely be expected, under existing circumstances, to disarm and

${ }^{1}$ Conference on the Limitation of Armament, Washington, D. C. November 11, 1921. put herself at the mercy of such a neighbor. France, also, makes common cause with Poland in fear of Red Russia, as well as of Germany, and all the other European countries follow in the wake. They have no option but to rely for security upon their own strength, for there is, as yet, no authority which can guarantee security to them. In the absence of great states from membership, the present League of Nations cannot be wholly relied upon for safety.

What is needed is a voice that will speak for all the nations of the earth in favor of disarmament and, afterwards, for the maintenance of security for each nation. If the United States would but again make common cause with all the European nations in the promotion of an all-embracing League of Nations a great step forward would be taken in the direction of such disarmament and security. Until there is a common understanding between the United States and Europe-including Germany and Russia-and until there is the necessary machinery and sanction to give effect to it, there can be no guaranty of peace. Indeed, the world might now at any time be again plunged into war by sheer weight of metal. Russia has taken the place occupied by Germany prior to 1914.

How to bring Russia into the new comity of nations is the present outstanding problem, and the problem is the more difficult because of the animosities which have been engendered by war and counter-war waged on her territories since the revolution and because of the complications arising out of the pre-war debts.

Reassociation, the Hope of Europe

A move of the United States in the direction of reassociation with Europe 
would probably affect Russian as well as German mentality, and I am sure that such a move would be heartily welcomed and responded to in England. We here look on helplessly at the waste in armaments of resources which are so sorely needed to restore the economic health of the nations, and we watch with alarm the' working out of the narrow particularisms which are the underlying motives of the policies of some countries. There is, for instance, the growing tendency towards export taxes on raw materials-a form of economic warfare from which, by the terms of her constitution, the United States is precluded from taking part. There are as yet the unrestricted and growing air forces and there is the impatience of labor everywhere and the propagation of wild theories by men and women who quite openly profess their hatred of the existing social order and their determination to destroy it, if they can.

The safeguard for civilization as against revolution is by full coöperation between America and Europe. And I am sure that such coöperation would be in the interest of both, for the prosperity of each is necessary for their common welfare. Take it on the low ground of cash. Europe is indebted to the United States to the tune of some ten thousand million dollars. She can pay all the easier in proportion as the way is found to her recovery. Failure to shoulder responsibilities - except by general agreement-would have a most injurious effect on her credit. On the other hand, the United States may suffer from economic and industrial indigestion by pushing her claims too fast. Great Britain is making provision for payment of interest in October of this year in accordance with arrangements made with the United States three years ago; and, if there is no agree- ment to the contrary, she will continue to deal with the American debt as she has already dealt with all external debts. Most other countries have, as a matter of fact, been paid off by Great Britain. But much of her debt to America Great Britain incurred in respect to war-allies who are also and independently indebted to her.

This question of inter-allied and European indebtedness presents many interesting features. There are questions of priority, of overlapping debts, and of the element of time of payment as bearing upon trade. It constitutes, in fact, such a labyrinth of economic as well as moral consideration as might well form the topic of special examination by experts and subsequent diseussion by delegates at a conference of the nations concerned. Credits and exchanges might, of course, be brought under review at the same time. There are countries so poor and helpless that they tend to drag others down to their level; there are fluctuations of exchanges from day to day so violent as to increase the difficulties of trade restoration.

These things, it is true, are being discussed now at Genoa, but Genoa suffers from the fact that United States delegates are not present for United States coöperation is in a special degree necessary for economic and financial rearrangement. The United States occupies a relatively strong position because of her comparative independence. She holds twothirds of the gold of the world and she has the raw materials and resources for sustenance of her people within her own borders. But, even so, she would gain by the gain of other countries, for her surplus manufactures would then find an outlet at present closed by lack of purchasing power of countries which have been most impoverished by the 
War. And her ultimate good depends upon her power of absorption more than upon the power of debtor countries to discharge their debt obligations.

\section{Possibilities of Coöperation}

I should like to see Genoa followed by another conference of all the powers, convened by the United States, at which the question of debts and indebtedness might be treated as a worldproblem rather than as a matter of isolated arrangement by debtor and creditor countries. I see no reason why neutral countries should not come in. They benefited by the War and might well be asked to bear some of its cost by underwriting some of its debts -an idea by the way which might also be applied to the liquidation of German liabilities for reparations. If there is no such conference, then I hope that the United States may be induced to come into some scheme of mutual help which may emerge from Genoa. But after all, either of these would be but a bad second best as compared with frank reassociation of the States in European affairs.

When, therefore, I am asked what the United States can do to help Europe I can only say that, in my judgment, she can do but little in isolation but that she might do a great deal in association. The Washington Conference did something towards world recovery and Genoa may do more, but neither of them would have been necessary if there had been full understanding and coöperation between Europe and America. I should like to see the problems which have emerged directly out of the War cleared out of the way as soon as possible and I should like to see the United States taking a hand in the clearance. Then the Supreme War Council would no longer linger superfluous upon the stage and the course would be clear for an all embracing League of Nations in which the United States could take a leading part.

After all, the conditions are different now from those obtaining two years ago. In the first place, there is a disposition now on the part of the League members to recast parts of the Covenant. And, in the second place, an International Court of Justice is now part of the League organization. It is the court for which the United States so long and honorably labored at the Hague and elsewhere. It is analogous to the Supreme Court of the United States, and is indeed largely the work of Mr. Elihu Root, the eminent United States citizen. Will the United States come over and further help us?

\title{
Self-Help Before American Coöperation in the Rehabilitation of Europe
}

\author{
By JoHn Jacob Rogers \\ Washington, D. C., Member of Congress from Massachusetts
}

$I^{s}$ $\mathrm{S}$ America's coöperation indispensable to European rehabilitation? Before $I$ attempt to answer this question from my own viewpoint, it may be interesting to note the attitude of
Europe. If we are to accept the utterances of European statesmen, the answer is unquestionably in the affirmative-that American coöperation is indispensable to European rehabilitation. 